\title{
New models of road transport system
}

\author{
Bauyrzhan Yedilbayev ${ }^{1 *}$, Zhanna Kozhamkulova ${ }^{1}$, Shinar Abdikul ${ }^{1}$, and Nazym \\ Tulebayeva $^{1}$ \\ ${ }^{1}$ Al-Farabi Kazakh National University , 050040, Almaty, Kazakhstan
}

\begin{abstract}
Transport and operational conditions include: the road - a relief, width of the carriageway, type and a paving condition, factor of coupling and flatness of a covering, a condition of roadsides, existence and quality of elements of the engineering equipment; the transport - a sort of transported cargo, intensity, stream density, a high-speed mode of movement; the weather and climatic - visibility, a precipitation, temperature, pressure and humidity of air; culture of operation - level of the organization of works and management, qualification and discipline of drivers, material base, quality of operational materials. Considering novelty of the problem considered in this article, and impossibility of coverage of all circle of questions on CTRE, it is called as «Introduction in city transport-road ecology», and the main terms, definitions and necessary standard data are provided in appendices.
\end{abstract}

\section{Introduction}

The city from the ecological point of view represents the difficult habitat of the person including natural and anthropogenous subsystems. The first is made by the atmosphere, a lithosphere, the hydrosphere and the biosphere, and the following subsystems enter into the second: production, town-planning and infrastructure. Degree of environmental friendliness of the city depends on a ratio of natural and anthropogenous subsystems.

Studying the city ecology by factual consideration includes town-planning ecology. Difference of town-planning ecology from the engineering is that a subject of discipline is not the separate enterprise, but territorial complexes and systems of the occupied places. Thus, territorial and town-planning environmental management is studied. From these positions the town-planning ecology is the key to planning-technical discipline. Methods of achievement of ecologically optimum compromise between anthropogenous systems of different level and environment are investigated in it. This branch of knowledge though treats engineering ecology, has its own features. Town-planning ecology as the new direction in system of ecological sciences appeared in last 15-20 years. In Kazakhstan, thanks to discoveries No. 144 and No. 269 of the academician of NAS RK Balabekov O. S. with his pupils, this fundamental problem started to be studied in recent years.

\footnotetext{
Corresponding author: b.t.yedilbayev@gmail.com
} 
In Kazakhstan influence on environment of the road network, representing set of engineering constructions is studied insufficiently. A construction of roads which belongs to road ecology are: withdrawal of local natural resources, land relief change, hydraulic engineering works (drainage of lands and bogs, change of the course of water currents, the device of embankments along reservoirs etc.) and technological pollution, and transport pollution if they operate. The zone of influence of the road on environment parameters depending on intensity of movement and in the absence of forests makes 100-200 m. In the presence of forests it is reduced to $75-150 \mathrm{~m}$. Anthropogenous loading of a road network is also shown: in scarifying fodder grounds; to deforestation; territory drainage; to mining; landscape violations. For example, on $1 \mathrm{~km}$ of the highway, depending on its category and value of the land lots, it is necessary to take away 2-7 hectares of the territory.

The vehicle is a source of: the increased health hazard and life of people because of possible involvement in road accidents (road accident); environmental pollution (EP) by harmful emissions; transport discomfort; consumption of natural resources, but at the same time bears positive social and economic and moral and psychological effects. Stated testifies to emergence of a new scientific branch - the transport ecology, studying various aspects of influence of vehicles (motor vehicles) on environment for all life cycle. However, the most important thing for the solution of problems of city ecology for Kazakhstan is the operational phase of motor transport, showing the basic (70-95\%) a source of pollution of the air environment practically all large centers of regions.

The car negatively influences practically on all components of the biosphere: atmosphere, water, ground resources, lithosphere and person. The motor transport, on the one hand, consumes oxygen from the atmosphere, and on another - throws out in it fulfilled gases, crankcase gases and hydrocarbons because of their evaporation from fuel tanks and a leakage of systems of supply of fuel. Exhausts from motor transport extend on city streets along roads, having harmful effects on pedestrians, inhabitants of nearby houses and vegetation. It is revealed that zones with maximum concentration limit excess on dioxide of nitrogen and oxide of carbon cover to $90 \%$ of an urban area, residential areas, the public, cultural and educational, research complexes, separate municipal and economic objects, and also a street road network (SRN). The analysis of branches of geo ecology with reference to the territory of the cities intended for building - town-planning, construction, transport and road shows that they, though are crossed in the separate directions, are mainly sent to factual consideration of environmental problems of the city. Motor vehicles and SRN in the inhabited environment are the main sources of pollution of air mass. Polluting substances (PS) of motor transport extend through roadsides of roads, sidewalks and buildings along the street inside quarters and yards of the residential area. Further PS extend on all the grad sphere.

However, this complex problem practically in all textbooks and manuals on ecology is considered factually, i.e. separately without interrelation. And questions of interrelation or mutual influence of emissions of motor transport in aggregate with infrastructure SRN (traffic lights, intersections, sidewalks, avenues, etc.) on environment aren't still considered in the world literature. Besides there are no data on distribution of exhaust gases (EG) of motor vehicle in the residential area near highways in any source. Therefore even it is difficult to expert to define the main sources of pollution of urban air environment.

Therefore in this book, the problem of city transport-road ecology (CTRE) for the first time is considered. 


\section{Modern problems of city transport-road ecology}

\subsection{Main concepts of city transport-road ecology.}

Master plans of development of the cities of Kazakhstan are developed on the basis of longterm prospects of their development as the cultural, historical, educational, scientific, financial and industrial centers of geographical regions taking into account a demographic forecast of a natural and mechanical increase in population, pendulum migrations and repatriated kazakhs. Besides we start with general schemes of moving of inhabitants of ecologically unsuccessful auls and consolidation of settlements, environmental management and the territorial organization of production forces. Thus ecological stability of development of this system where about a half population lives is considered insufficiently.

The city from the ecological point of view represents the difficult habitat of the person including natural and anthropogenous subsystems. The first is made by the atmosphere, a lithosphere, the hydrosphere and the biosphere, and the following subsystems enter into the second: production, town-planning and infrastructure.

Degree of environmental friendliness of the city depends on a ratio of natural and anthropogenous subsystems. However it moves to quality standard. For an objective assessment it is necessary to use quantitative data which usually are basic data at design and building of the cities and settlements. According to Construction Norms and Regulations of RK 3.01-01-2002 of the city are subdivided into city intended for building, production and landscape and recreational territories.

In the cities with primary low building natural landscapes prevail: the natural land relief, small rivers, reservoirs and aryks, parks, forest parks and other green plantings, i.e. prevails a natural zone. The spatial unity of building, green massifs and a surface of the water is provided. Such settlements are called the city park, the garden city, instead of the city of power engineering specialists, chemists, miners etc. Such cities are considered [2] as ecopolice - natural and anthropogenous systems. There is an opinion that optimum population density in their territories shouldn't exceed 100 people/hectares. In this case it is possible to keep the planted trees and shrubs spaces, on the area equal to the territories occupied by asphalt coverings, buildings and various city constructions.

However such settlements are uneconomical, as demand branch of lands expensive and necessary for agriculture, extended street road networks, communication, and water power supply.

In the world [1] the tendency of consolidation of settlements is traced. Modern capital cities of the states, the centers of agglomerations, the industrial and economic centers everything more represent the dense urbanized educations. The settlements occupying big intensively used territories are born. In world practice there are examples of settlements in which one city flows in another and the whole areas turn into the uniform megalopolis.

Proceeding from the stated it follows that regularities of functioning of an ecosystem of the large cities can't be transferred into the small. Let's consider existing classification. According to RK 3.01-01-2002 Construction Norms and Regulations city and rural settlements depending on design population for settlement term (to 20years) are subdivided into groups (table 1). 
Table 1. Classification of group of settlements

\begin{tabular}{|c|c|c|}
\hline Groups of settlements & \multicolumn{2}{|c|}{ Population, thousand people } \\
\cline { 2 - 3 } & Cities & Rural settlements \\
\hline The largest & Above 1000 & Above 5 \\
The large & From 500 to 1000 & $3-5$ \\
& $250-500$ & $1-3$ \\
The big & $100-250$ & $0.2-1$ \\
Average & $50-100$ & $0.05-0.2$ \\
The small* & $20-50$ & To 0.05 \\
& $10-20$ & \\
& To 10 & Note \\
\hline
\end{tabular}

In N.V.Maslov's book [1] city ecology is presented as:

1. Dynamically functioning system. It possesses such developed subsystems, as cityforming base, housing and communal services, system of social service, including education, medicine and services, leisure and rest establishments, transport infrastructure. Therefore the cities have special attractive force.In process of social and demographic changes city structures are transformed, subsystems are modernized. Operation of these subsystems is intensified. The cities develop.Management of development is based on the analysis of town-planning activity at all stages: from development of the project before long-term monitoring at operation and reconstruction. Therefore in settlements people artificially create and regulate substance and energy streams, i.e. the mankind in many respects influences these processes, forms and breaks off natural trophic chains. It creates the environment of the dwelling as the material sphere and city architecture represent result of activity of the person, and they prevail over natural processes. This activity is especially notable at operation of city structures, their functional use, continuous transformation and development, and the need for it arises everywhere under the pressure of an economic, social, and demographic and transport situation.

2. Heat-sink systems. The balance of harmful substances in its limits is positive, as a rule, and also conducts to accumulation of a previous waste and transformations. It is enough to note growth of an occupation layer. In some cities its thickness reaches $10 \mathrm{~m}$. The natural land relief is broken; there are heights, landslides and failures. Natural superficial waterways silt and change the direction. Often they turn in underground, flowing in collectors. Natural self-cleaning of water stops and consequently the content of harmful impurity increases, the composition of water changes. There is a certain regularity of accumulation in the city, not peculiar to wildlife, the phenomena. The atmosphere, gets littered with emissions, soils collect harmful substances. There are also other negative consequences of an urbanization with which the nature can't consult as the ability to self-restoration is lost.

3. Dependent ecosystem. If all ecosystems are open, then cities are super open. The city can't support the population. He breathes another's air and drinks another's water. At the same time with it throws out to the biosphere a large number of products of the activity. It is visible from table 2 the sizes of the territories necessary for preservation of stability of such city ecosystem and reproduction of deficiency of these resources are also shown. From the table follows that about 8-11 million hectares of territories are 
necessary for this purpose, i.e. 1 thousand times more, than occupies the city.Besides consumption of natural resources and energy of the city make a large quantity of a waste. So, according to some information the millionth city annually throws out about 15 million $t$ of a dust, water vapor and other toxic substances. Therefore million settlements on our planet act as the main centers of anthropogenous indignation in the biosphere.

Table 2. The look-ahead resources consumption of the city with the population of 1 million people and the area of 20 thousand hectares.

\begin{tabular}{|c|c|c|c|c|}
\hline $\begin{array}{l}\text { Name of the } \\
\text { component or } \\
\text { resource }\end{array}$ & $\begin{array}{c}\text { Consumption } \\
\text { by the city }\end{array}$ & $\begin{array}{l}\text { Reproduction in } \\
\text { the city }\end{array}$ & Deficiency & $\begin{array}{c}\text { Territory } \\
\text { necessary for } \\
\text { covering } \\
\text { deficiency } \\
\text { (thousand } \\
\text { hectares) } \\
\end{array}$ \\
\hline 1 & 2 & 3 & 4 & 5 \\
\hline $\begin{array}{c}\text { Atmospheric } \\
\text { oxygen }\end{array}$ & $30 \mathrm{mln} \mathrm{t}$ & $25-30$ th $t$ & $29.7 \mathrm{mln} t$. & $5000-6000$ \\
\hline Water & $500 \mathrm{mln} \cdot \mathrm{m}^{3}$ & 5 thousand $\mathrm{m}^{3}$ & $500 \mathrm{mln} \mathrm{m}^{3}$ & $1500-2000$ \\
\hline $\begin{array}{c}\text { Soil and } \\
\text { vegetative } \\
\text { cover for the } \\
\text { organization of } \\
\text { places of mass } \\
\text { rest }\end{array}$ & $\begin{array}{l}5 \text { thousand } \\
\text { hectares }\end{array}$ & - & $\begin{array}{c}1000-2000 \text { th. } \\
\text { hect. }\end{array}$ & $1000-2000$ \\
\hline $\begin{array}{c}\text { Raw materials } \\
\text { for the industry, } \\
\text { constructions, } \\
\text { etc. }\end{array}$ & $10-12 \mathrm{mln} t$ & - & $10-12 \mathrm{mln} t$ & $40-50$ \\
\hline $\begin{array}{c}\text { Conditional } \\
\text { fuel }\end{array}$ & $8-9 \mathrm{mln} t$ & - & $8-9 \mathrm{mln} t$ & $25-30$ \\
\hline Foodstuff & $1 \mathrm{mln} t$ & - & $1 \mathrm{mln} t$ & $500-600$ \\
\hline
\end{tabular}

4. No equilibrium ecosystem. As a rule development and functioning of city structures is defined not by nature laws, but by need of people. Such structures grow out of destructive and creative activity of many generations. The nature reacts to transformations ambiguously. The city consumes substance and energy streams in much bigger degree, than makes. Ecological equilibrium speaks artificial attraction from the outside of a large quantity of streams of substances and energy, therefore ecological equilibrium of ecological systems of the city extremely unstably.Processes of consumption of resources (including products) and allocation of a waste strongly differ from circulation of substances in the nature. Efficiency of city ecosystems is insignificant, biomass doesn't provide zoo mass, and reliability of functioning of natural and town-planning systems can be reached by other means, rather than it is provided under natural conditions. Feed by the food from the outside is necessary. The population of the large cities receives agricultural products not only from suburbs, but also from other areas and regions.

5. Conglomerate of artificial ecological Microsystems: buildings and constructions of inhabited, industrial and municipal and warehouse building. These architectural and engineering objects are the closed environments of continuous or temporary dwelling of citizens. The hygienic of internal spaces of buildings in many respects depends on purity of air in rooms and air exchange, i.e. removal outside of harmful substances. Also the 
heat-humidity mode essentially influences: relative humidity of air, its temperature in a placement and on surfaces of protections. Special value has heat exchange with the external environment. In modern buildings often apply designs, furnish, furniture and other equipment from toxic materials. They negatively influence people.

Buildings and constructions, being closed, don't represent independent ecological systems. They are connected with environment. Gases, a dust and live microorganisms are transferred to rooms from the polluted external air. In building appropriate aeration and insolation modes that aggravate an ecological situation aren't always provided. Ecological comfort of the internal environment is influenced essentially by noise pollution of territories adjacent to building. Also disturbers of the vibrating phenomena, for example rail transport similarly influence. Electromagnetic radiation and radiation negatively affect internal habitat. The human health is threatened. They start to have different diseases, often irreversible.

Having provided 5 ecological characteristics of the city formulated in the book [1] the task started with to show complexity of a considered ecosystem. They should be considered as research methodology in this area.

At the solution of problems of city ecology the majority of researchers, architects, designers and experts of the various directions of a science and equipment start with a permanent assessment of a condition of habitat of the person and carry out it factually.

Forecast and formation of favorable bioclimatic conditions by means of planning, building and accomplishment - one of important tasks of the project of detailed planning (PDP) of the residential area.

Continuing methodology of studying ecology of city by factual consideration, we will pass to town-planning ecology.

Difference of town-planning ecology from the engineering is that a subject of discipline is not the separate enterprise, and territorial complexes and systems of the occupied places. Thus, territorial and town-planning environmental management is studied.

From these positions the town-planning ecology is key planning-technical discipline. Methods of achievement of ecologically optimum compromise between anthropogenous systems of different level and environment are investigated in it.

Even experts often confuse town-planning ecology to ecological construction or the construction ecology approached to specifics of construction activity [2]. This branch of knowledge though treats engineering ecology, has its own features. It as the new direction in system of ecological sciences appeared in last 15-20 years. In Kazakhstan this fundamental problem began to be engaged in recent years thanks to discoveries No. 144 and No. 269 of the academician of NAN RK of Balabekov O. S. with his pupils.

Ecological construction is understood as set of the methods connected with acceptance and implementation of engineering decisions on construction of buildings, constructions and their complexes which are most compatible to the surrounding natural and social environment.

The solution of the majority of problems of city ecology is connected with achievements of scientific and engineering activity in the field of creation of safe technologies, systems of automobiles, cars, mechanisms and installations.

To engineering ecology belongs the field of knowledge studying influence of the industry and transport from the separate enterprise, a vehicle, the car, installation to a technosphere as a whole on environment and development of the technical decisions providing ecological safety in a technosphere. The term "engineering ecology", as well as the discipline with the same name, appeared rather recently, and the main emphasis here placed on studying of technical systems of ecological safety.

1. Development of engineering ecology in Kazakhstan began in 70-80s of the last century. The school of sciences created in the city of Shymkent in this direction of a science of 
education carried out basic and applied researches on studying and development:

processes and devices for cleaning and utilization of emissions in the atmosphere;

2. ecologically safe technology in various industries;

3. methodologies of creation of without waste and low-waste complexes in regions;

4. normative documents, state standard specifications and specifications.

5. Therefore, assuming that this is a problem so far exhausted, go to the components of environmental engineering as applied to transport.

Transport has on the environment [6], individual ecosystems, both positive and negative effects. On the one hand, it violated the principles of the functioning of ecosystems, they can degrade and become unstable, but on the other hand - transport provides the movement of material flows (construction of roads, airfields, harbors, and the establishment of transport equipment, organization and control of movement of vehicles, storage of goods) provides comfortable living conditions of people.

The vehicle is a source of danger to the health and lives of people because of possible involvement in road traffic accidents (RTA), EP by harmful emissions, the transport of discomfort, the consumption of natural resources, yet has a positive socio-economic and moral-psychological effects (Table 3).

Transport is a set of techno-economic structure, designed to transport goods and people, and includes: - System design, construction, reconstruction, repair, maintenance of roads, bridges, tunnels and other structures; - Automotive, aviation, shipbuilding industry, construction, road and transport engineering; - The scope of operation and maintenance of these machines, maintaining the performance of road transport, road infrastructure and traffic services; - Construction materials, tires, fuels and oils, electrical devices, spare parts and fluids.

Table 3. Effect of car ownership on the environment

\begin{tabular}{|c|c|}
\hline Positive aspects & Negative aspects \\
\hline $\begin{array}{l}\text { The development of trade, political and } \\
\text { cultural ties, increased contacts }\end{array}$ & $\begin{array}{c}\text { Violation of the gas and energy balance in the } \\
\text { atmosphere }\end{array}$ \\
\hline $\begin{array}{l}\text { Promoting scientific and technological } \\
\text { progress, providing jobs }\end{array}$ & $\begin{array}{l}\text { Depletion of the atmosphere, mineral resources, } \\
\text { fresh water }\end{array}$ \\
\hline $\begin{array}{l}\text { The inclusion of transport in the production } \\
\text { processes and reducing innovational cycles } \\
\text { in the production of goods }\end{array}$ & Destruction of living organisms in road accidents \\
\hline $\begin{array}{c}\text { The feeling of freedom and independence of } \\
\text { the individual }\end{array}$ & $\begin{array}{c}\text { Poisoning of biological resources, including } \\
\text { plants, animals, human }\end{array}$ \\
\hline Empowerment to live in good conditions & Increased stress load traffic participants \\
\hline $\begin{array}{l}\text { The expansion of living space for the } \\
\text { individual }\end{array}$ & $\begin{array}{l}\text { Reduction of the living space through the } \\
\text { exclusion of areas of territories }\end{array}$ \\
\hline $\begin{array}{c}\text { Increased availability of social and personal } \\
\text { services for consumers }\end{array}$ & $\begin{array}{l}\text { The reduction of biological productivity of the } \\
\text { landscape }\end{array}$ \\
\hline $\begin{array}{l}\text { Meeting the needs of a wide range of } \\
\text { products, fresh produce }\end{array}$ & $\begin{array}{c}\text { Violation of urban public space of harmony and } \\
\text { rural landscapes }\end{array}$ \\
\hline $\begin{array}{l}\text { Feeling the joy of driving fast, comfort and } \\
\text { convenience in inclement weather }\end{array}$ & $\begin{array}{l}\text { Rising taxes and costs associated with transport. } \\
\text { Changing the structure of the family budget. }\end{array}$ \\
\hline
\end{tabular}

Objects of transport - cars, motorcycles, airplanes, ships, locomotives and other vehicles equipped with power units, and ensuring the implementation of transport and engineering structures (roads, bridges, overpasses). 
Life cycle (LC) method of transport - chronologically expressed sequence of stages: extraction and processing of raw materials, production engineering, maintenance, roadbuilding materials, transportation, storage, production (manufacturing facility); use, disaster recovery and recycling equipment or facilities.

At each stage of the life cycle is the consumption of energy, construction, road construction and maintenance materials, manufacturing processes are accompanied by emission of harmful and toxic substances. They contribute to air pollution, water or soil, depletion of natural resources in the implementation of the life cycle of the object, since they can accumulate in the biosphere landscapes. Harm to the environment, these effects occur at different stages of product life cycle, have, in cases where:

1. Polluting emissions, discharges exceed the maximum permissible concentrations of substances or noise, vibration, residual heat, electromagnetic radiation and radioactive exceed the prescribed levels;

2. The consumption of materials and energy exceeds the established standards;

3. The content of environmentally harmful substances and materials used in the components exceeds the limit;

4. Waste arising in the life cycle transportation facilities, is in violation of the rules.

5. Emerging as vibroacoustic, electromagnetic, thermal radiation is factors of direct action and cannot accumulate. Therefore, the methodology of the life cycle of these kinds of effects cannot be applied [3].

The foregoing indicates the emergence of a new scientific branch - the transport of Ecology, the study of various aspects of the impact of motor vehicle on the environment for the entire life cycle. However, to solve the problems of the urban environment in Kazakhstan is the most important step operation of motor vehicles, which is the main (70$95 \%$ ) source of air pollution in virtually all regions of the centers.

As follows from the above in the transport sector and transport facilities is a system design, construction, reconstruction, repair and maintenance of roads. This category applies to the urban road network (SRN) of cities.

In Kazakhstan, the environmental impact of the road network, which is a set of engineering structures, has been insufficiently studied. It is dangerous to their effects: these include the construction of roads: the removal of local natural resources, changes in terrain, hydraulic works (drainage of land and wetlands, changing the bed of watercourses, the unit of embankments along the water, etc.) and technological contamination, and in their operation of a transport of pollution.

The road network of Russia and transport infrastructure has a negative impact on the environment in the area of more than 15 million hectares.

The subject of road environment should be:

1. Alienation of land for roads and transport infrastructure, the zone of contamination, erosion, cutting of forests, a quarry for the extraction of construction materials;

2. The removal of mineral, water, energy resources;

3. Pollution by harmful substances, noise, vibration, heat, electromagnetic and ionizing radiation environment (air, water, soil, biota), enterprises of transport and road infrastructure and roads as linear structures (traffic);

4. Driving culture motor vehicle drivers and their passengers.

With respect to the subject of the study we are interested only in air pollution residential area of the city, including residential areas, public cultural, educational, research centers, individual municipal utility facilities, as well as the road network. The latter concept requires some explanation.

Street - space between two rows of houses in the village for the passage and accommodation, as well as two rows of houses with passage, passing between them. 
The Road - furnished or adapted and used for vehicular traffic strip of land surface or an artificial structure. The road includes one or more of the roadways, as well as the tram lines, pavements and roadsides, as well as dividing strip.

The urban road network (URN) - a set of streets, squares and roads of city and district level, linking the residential and industrial areas of the city among themselves, which are used to traffic and pedestrians. The following planning scheme SRN: radial, radial-circular, square, rectangular-diagonal, triangular, combined, and free. The density of SRN is ratio of the total length of streets in the appropriative km land area of the city or area in square kilometers.

This should highlight the passive zone inside of the road network outside the limits of streets and roads. In them there is practically no movement of the motor vehicle. This is a sleeping area of the city, kindergartens, schools, playgrounds, micro zones for everyday leisure. We denote them as the courts, or of inter-residential area.

Analysis of the branches of Geoecology in relation to residential areas of cities - urban planning, construction, transport and road shows that, although they overlap in some areas, mainly aimed factual consideration of environmental issues. Exchange and SRN in the living environment are the main sources of pollution of the air mass. Contaminants of vehicles arising on the road, spread through the side of roads, sidewalks, existing space between vegetation and buildings, located along the streets inside neighborhoods and courtyards of the residential area. Further, pollutants spread throughout grad sphere.

Here there is a complex mechanism of formation of bio-climatic and environmental conditions because of interaction: motor vehicle on the road and its infrastructure (traffic lights, curb). However, these phenomena cannot be the subject of one branch of science. The fundamental radiation to be based on the laws of aerodynamics, heat and mass transfer, statistics, as well as certain provisions of urban planning, transport and road ecology. In the analysis of these laws and regulations should first start from the human ecology.

Thus, the processes studied are the objects of City-Transport and Road Ecology (CTRE), allowing establishing the fundamental laws of the transport of pollutants in the air basin residential areas of cities. Basic terms and definitions in CTRE are given in Categories and design parameters of streets and roads.

Table 4. Technical classification of roads.

\begin{tabular}{|c|c|c|c|}
\hline \multirow[t]{2}{*}{ Category of roads } & \multicolumn{2}{|c|}{ Estimated traffic } & \multirow{2}{*}{$\begin{array}{c}\text { National economic and } \\
\text { administrative importance } \\
\text { of road }\end{array}$} \\
\hline & $\begin{array}{l}\text { Reduced to } \\
\text { cars, units/ } \\
\text { day }\end{array}$ & $\begin{array}{c}\text { in terms of } \\
\text { transport, bus/ } \\
\text { day }\end{array}$ & \\
\hline I a & $\begin{array}{l}\text { More than } \\
14000\end{array}$ & More than 9000 & $\begin{array}{l}\text { Highway of international } \\
\text { and national importance }\end{array}$ \\
\hline $\mathrm{Ib}$ & $\begin{array}{l}\text { More than } \\
14000\end{array}$ & More than 7000 & $\begin{array}{l}\text { High-speed highways of } \\
\text { international and national } \\
\text { importance (not classified to } \\
\text { Ia) }\end{array}$ \\
\hline II & $6000-14000$ & $3000-7000$ & $\begin{array}{c}\text { High-speed highways of } \\
\text { international and national } \\
\text { importance (not classified to } \\
\text { Ia, Ib) }\end{array}$ \\
\hline IV & $200-2000$ & $100-1000$ & $\begin{array}{c}\text { national highways and local } \\
\text { roads (not classified Ib, II, } \\
\text { III) }\end{array}$ \\
\hline $\mathrm{V}$ & Till 200 & Till 100 & $\begin{array}{l}\text { Highways of local roads } \\
\text { (except classified to III and }\end{array}$ \\
\hline
\end{tabular}




\begin{tabular}{|c|c|c|c|}
\hline Category of roads & \multicolumn{2}{|c|}{ Estimated traffic } & $\begin{array}{c}\text { National economic and } \\
\text { administrative importance } \\
\text { of road }\end{array}$ \\
\hline & $\begin{array}{c}\text { Reduced to } \\
\text { cars, units/ } \\
\text { day }\end{array}$ & $\begin{array}{c}\text { in terms of } \\
\text { transport, bus/ } \\
\text { day }\end{array}$ & \\
\hline & & & IV) \\
\hline
\end{tabular}

Table 5. Category of streets and roads.

\begin{tabular}{|c|c|}
\hline Category of streets and roads & The main importance of roads and streets \\
\hline $\begin{array}{l}\text { trunk roads: } \\
\text { traffic speed }\end{array}$ & $\begin{array}{l}\text { High-speed transport link between the remote } \\
\text { and industrial planning districts in the largest } \\
\text { and most major cities outputs to external roads, } \\
\text { at airports, major public recreation areas and } \\
\text { settlements in the settlement. Intersection with } \\
\text { the main streets and roads in different levels. }\end{array}$ \\
\hline controlled traffic & $\begin{array}{l}\text { Transport links between areas of the city in } \\
\text { certain areas, and areas predominantly freight } \\
\text { traffic, carried out outside the residential } \\
\text { development, the outputs of the external roads, } \\
\text { cross streets and roads are generally in the same } \\
\text { level. }\end{array}$ \\
\hline $\begin{array}{c}\text { main streets of city traffic } \\
\text { main streets of continuous motion }\end{array}$ & $\begin{array}{l}\text { Transport links between residential, industrial } \\
\text { areas and community centers in the major and } \\
\text { large cities, as well as other main streets, town } \\
\text { and outside roads. Provision of traffic on the } \\
\text { main directions at different levels. }\end{array}$ \\
\hline controlled traffic & $\begin{array}{l}\text { Transport links between residential, industrial } \\
\text { areas and community centers, planning districts, } \\
\text { to outputs highway streets and roads and } \\
\text { external roads. Intersection with the main streets } \\
\text { and roads are generally in one direction. }\end{array}$ \\
\hline \multirow[t]{2}{*}{ Transport and pedestrian } & $\begin{array}{l}\text { Transport and pedestrian connections between } \\
\text { residential areas and between residential and } \\
\text { industrial areas, community centers, links to } \\
\text { other main streets. }\end{array}$ \\
\hline & $\begin{array}{l}\text { Pedestrian and transport links (mostly public } \\
\text { transport) within the planning area. }\end{array}$ \\
\hline $\begin{array}{c}\text { Pedestrian and transport } \\
\text { Streets and local roads } \\
\text { streets in residential area }\end{array}$ & $\begin{array}{l}\text { Transport (freight without a permit and public } \\
\text { transport) and the pedestrian connection in the } \\
\text { residential districts (districts), exit to the main } \\
\text { streets and roads of controlled movement. }\end{array}$ \\
\hline $\begin{array}{l}\text { Streets and roads in scientific and industrial, } \\
\text { municipal and industrial and warehouse areas }\end{array}$ & $\begin{array}{l}\text { Transport connection mostly cars and trucks } \\
\text { within the zones (areas), the outputs on the main } \\
\text { city roads. The intersections with streets and } \\
\text { roads arranged in a single level. }\end{array}$ \\
\hline
\end{tabular}


Table 6. Estimated parameters of urban streets and roads.

\begin{tabular}{|c|c|c|c|c|c|c|}
\hline $\begin{array}{l}\text { Category of } \\
\text { streets and } \\
\text { roads }\end{array}$ & $\begin{array}{c}\text { estimated } \\
\text { speed, km } \\
/ \mathbf{h}\end{array}$ & $\begin{array}{l}\text { width } \\
\text { of } \\
\text { traffic } \\
\text { lanes, } \\
\text { m }\end{array}$ & $\begin{array}{l}\text { number of } \\
\text { lanes, }\end{array}$ & $\begin{array}{c}\text { the } \\
\text { smallest } \\
\text { radius of } \\
\text { the } \\
\text { curves in } \\
\text { the } \\
\text { plane, } m\end{array}$ & $\begin{array}{l}\text { slope of the } \\
\text { largest } \\
\text { longitudinal, }\end{array}$ & $\begin{array}{c}\text { width of } \\
\text { the } \\
\text { pedestrian } \\
\text { walkway }\end{array}$ \\
\hline 1 & 2 & 3 & 4 & 5 & 6 & 7 \\
\hline $\begin{array}{l}\text { Trunk roads: } \\
\text { speed } \\
\text { movement }\end{array}$ & 120 & 3,75 & $4-8$ & 600 & 30 & - \\
\hline $\begin{array}{l}\text { of the } \\
\text { controlled } \\
\text { traffic }\end{array}$ & 80 & 3,50 & $2-6$ & 400 & 50 & - \\
\hline $\begin{array}{l}\text { Trunk roads: } \\
\text { citywide } \\
\text { importance, } \\
\text { continuous } \\
\text { movement of } \\
\text { the } \\
\text { controlled } \\
\text { motion } \\
\end{array}$ & $\begin{array}{c}100 \\
80\end{array}$ & $\begin{array}{l}3,75 \\
3,50\end{array}$ & $\begin{array}{l}4-8 \\
4-8\end{array}$ & $\begin{array}{l}500 \\
400\end{array}$ & $\begin{array}{l}40 \\
50\end{array}$ & $\begin{array}{l}4,5 \\
3,0\end{array}$ \\
\hline $\begin{array}{l}\text { Streets and } \\
\text { local roads } \\
\text { The streets } \\
\text { in the } \\
\text { residential } \\
\text { area }\end{array}$ & 30 & 3,00 & $2-3$ & 50 & 80 & $\begin{array}{l}1,5 \\
1,5\end{array}$ \\
\hline $\begin{array}{c}\text { Streets and } \\
\text { roads of } \\
\text { scientific } \\
\text { and } \\
\text { industrial, } \\
\text { municipal } \\
\text { and } \\
\text { industrial } \\
\text { and } \\
\text { warehouse } \\
\text { areas, park } \\
\text { roads }\end{array}$ & 50 & 3,50 & $2-4$ & 50 & 70 & 1,5 \\
\hline $\begin{array}{l}\text { Directions: } \\
\text { the main } \\
\text { secondary }\end{array}$ & $\begin{array}{l}40 \\
30 \\
\end{array}$ & $\begin{array}{l}2,75 \\
3,50 \\
\end{array}$ & $\begin{array}{l}2 \\
1 \\
1\end{array}$ & $\begin{array}{l}50 \\
25\end{array}$ & $\begin{array}{l}70 \\
80\end{array}$ & $\begin{array}{r}1,0 \\
0,75 \\
\end{array}$ \\
\hline $\begin{array}{l}\text { Pedestrian: } \\
\text { The main } \\
\text { streets } \\
\text { Secondary } \\
\text { streets }\end{array}$ & - & $\begin{array}{l}1,00 \\
0,75\end{array}$ & $\begin{array}{l}\text { According } \\
\text { to the } \\
\text { calculation } \\
\text { According } \\
\text { to the } \\
\text { calculation }\end{array}$ & - & 60 & $\begin{array}{l}\text { According } \\
\text { to the } \\
\text { project } \\
\text { According } \\
\text { to the } \\
\text { project }\end{array}$ \\
\hline $\begin{array}{l}\text { Bike lanes: } \\
\text { separate, } \\
\text { isolated }\end{array}$ & $\begin{array}{l}20 \\
30\end{array}$ & $\begin{array}{l}1,50 \\
1,50\end{array}$ & $\begin{array}{l}1-2 \\
2-4\end{array}$ & $\begin{array}{l}30 \\
50\end{array}$ & $\begin{array}{l}40 \\
30 \\
\end{array}$ & $\begin{array}{l}- \\
-\end{array}$ \\
\hline
\end{tabular}


The width of streets and roads are calculated depending on the intensity of traffic and pedestrians, of being placed within the profile elements (roadways, technical strips for laying underground utilities, sidewalks, green space), taking into account the sanitary requirements and the requirements of civil defense. Typically, the width of streets and roads in the red lines is accepted, m: Highway-50-75, main streets-40-80; streets and local roads$15-25$.

\section{Summary}

Let us analyze the system "driver-car-SRN-BFS" in the form of brief conclusions arising from the materials of the previous sections. The purpose of this consideration is to simplify the problem under consideration by excluding the objects of study, because of their sufficient knowledge or Vice versa because of the impossibility of solving the existing problem due to the lack of data and methods of study at this time:

1 The first object is the driver, his psychological stability, culture and driving experience. Unfortunately, there is a lot of talk about this factor, but there is no single criterion for its assessment. To solve this problem, if possible, it is necessary to involve purposefully specialists and scientists of various branches of science (medicine, pedagogy, statistics, Economics and management). Everyone notes the unpredictability of the behavior of each autotransport driver (perhaps, except for Shuttle buses, taxis), as well as the impact on his momentary decisions of random factors (accidents, weather) and fluctuations associated with the season, holidays, the nature of the evening before, etc.in Addition, he can choose one route in the morning to achieve the same goal, in the afternoon - the second, and in the evening - the third. One driver chooses the shortest path, and the secondthe fastest and safest. Some, for this purpose go in the opposite direction, use bypass roads. Beginners to drive a car choose SRN with a lower intensity of traffic and traffic lights. Therefore, this object was excluded from the program of this study;

2 in recent years, separate sources [4] of negative impact of transport facilities on the environment have been classified, cause-and-effect relationships have been established to manage the level of environmental safety of the transport complex. Can consider methodically completed the development phase of calculation methods for evaluating the specific (per unit of run) emissions of single vehicles and running (per unit path length per unit time) of emissions from traffic flows on the road network, pollution of the wayside toxic substances, the formation of the fleet of the region using environmental criteria. The measure of environmental safety (cleanliness) of vehicles for various purposes and environmental requirements for these objects are established, the causal relationships of the influence of various engineering, technological and organizational factors on this indicator are determined [5].

Thus, normalization of ecological qualities of cars is completed [6], in Russia the ecological classification of motor vehicles depending on the level of emissions of harmful (polluting) substances is established [7]. Long-term approbation of methods for calculation of autotransport (ATS) emissions, assessment of their impact on the human body and environment, on the basis of which the equivalent economic damage was established [8].

However, not the regularities of "environmental behaviour" of a set of cars on a street road network of large cities, which, on the one hand, impose constraints on the behavior of single vehicles in a transport stream, the motion control algorithms and the other - do not allow to extend the principle of additivity to estimate emissions of harmful substances traffic flows and Park, consisting of certain car brands. Environmental assessments are no longer limited to the calculation of gross emissions of individual substances, the task is to determine and calculate the concentrations of impurities in the atmosphere over a large area 
of territory, taking into account the transformation of individual substances, the risk of human diseases.

The most important thing is that the relationship has not yet been established in the process of movement of cars in the street flow among themselves;

3 the Third object-the street and road network (SRN) of large cities is the cause of high density of traffic flows, low traffic intensity, frequent pre-traffic and congestion situations [9]. All this together with the technical condition of roads and elements of SRN significantly affects the condition of the air basin around the main streets and roads.

Abroad and in Kazakhstan, the impact of roads and their technical condition on the environment has been well studied, and the impact of the SRN of cities is only qualitative. The empirical approach based on statistical data prevails. This is because of the complexity of the problem.

So, until now, the exact definition of the concept of "congestion" and" traffic jam " does not exist. There are no methods to measure the amount of congestion due to the lack of a common point of view that there is congestion. Conventionally, there are two types of congestion characteristic of the largest and largest cities:

Restricted in travel due to the congestion of the network;

Мертв "dead" congestion-occurs either in the event of an accident, or when drivers go to the oncoming lane on both sides, as a result they are "intertwined" with each other (they can still block trolleybuses and trams).

It is interesting that the typical problem for large cities of the formation of before jam and congestion has not yet been fully studied by anyone. So recently, the national research center Los Alamos, known as the birthplace of the atomic bomb, focused on the study of traffic flows [8]. The Center's scientists say " " the State of Affairs in this area today is such that despite significant progress, a full understanding of the nature of traffic jams has not yet been achieved." It can be stated that now humanity is still closer to understanding the processes of the origin of the Universe than the formation of traffic jams. The authors Shedenov et al. in their research considered a brief overview of the examples of the application of three modeling paradigms to create models related to road transport. We considered the following paradigms: discrete event, Agent based, and system dynamics [9]. The following authors Sharapiyeva et al. investigated existing approaches to assessing the energy efficiency of transport and logistics infrastructure. They also showed the method of placement of logistics facilities and analyzed the impact of market factors on the placement of logistics centers [10]. The development of the transport system affects the development of tourism and digital education. An important goal of tourism development in the Republic of Kazakhstan is the formation of a socially and environmentally oriented, competitive and profitable tourism industry that can provide the needs of tourists with various tourist services that bring income to the country and newly created jobs, including those associated with tourism in the sectors of the economy $[11,12]$.

Note only that the jam has a random or fluctuating character. If in one place of Almaty there was a traffic jam, then on the second day the density of the flow will decrease here;

4 the Last object-buildings and facilities along the street (BFS) do not have a significant impact on the envoronment. On the contrary, they perceive the main technogenic load from motor transport and the road network. However, if they are located along the street, they have a screening and filtering role in the propagation of noise and NOISE from vehicles further into the courtyards and quarters (neighborhoods) of residential areas of the city. Thus BFS constantly perceives on itself blow of the first waves of pollution, noise, vibration, thermal, electromagnetic and radiation influence of technogenic system "carSRN".

Thus, the object of this study is the system "ATS-SRN-BFS", which is a housing and transport complex in the normalized residence of residents and traffic on a normal working 
day, and the subject of the study is the modern problems of CTRE of large cities, which allowed to formulate the purpose and objectives of the research.

\section{References}

1. N. V. Maslov Town-planning ecology (2003)

2. L.V. Peredelski, O. E. Prikhodchenko, Construction ecology (2003)

3. M. V. Butorina, L.F. Drozdova, N. I. Ivanov, Engineering ecology and ecological management (2004)

4. B.T. Yedilbayev, Ecol. Know. Sci. Soc., 240-246 (2006)

5. V.N. Lukanin, U.V. Trofimenko, Promishlenno-transportnaia ecologia (2001)

6. M.M. Bekmagambetov, Road transport in Kazakhstan: stages of establishment and development (2003)

7. U.A. Poliakov, Mot. Trans. Oper. Maint. Rep., №2, 23-26 (2007)

8. B.N. Korganbayev, A.A. Volnenko, B.T Yedilbayev,. HKTU, № 2, 60-63 (2006)

9. J. Tolujevs, O. Shedenov, G. Askarov, Transp. Telecom. J., 19(1), 1-9. (2018)

10. M. D Sharapiyeva, K. Duissekul, N. Gulmira, K. Zhanna, Int. J. Ene. Econ. Pol., 9(5), 331 (2019)

11. S. Ziyadin, G. Dauliyeva, Z. Kalymbekova, A. Turlybekova , IBIMA, 2065-2070 (2017)

12. K. Ordov, A. Madiyarova, V. Ermilov, N. Tovma, M. Murzagulova, Int. J. Mech. Eng. Tech., 10(2), 1319-1330 (2019) 